\title{
New Student Admission Management Based Online
}

\author{
Masani $^{1 *}$, Happy Fitria ${ }^{2}$, Alfroki Martha ${ }^{2}$ \\ ${ }^{1}$ SMA Negeri 1 Banyuasin II \\ ${ }^{2}$ Universitas PGRI Palembang \\ * Corresponding author. Email: masanis.pd@gmail.com
}

\begin{abstract}
The key research objectives are to evaluate the management of new student admissions online at Banyuasin II, Banyuasin Regency, State Senior High School I. Qualitative research approaches, collection strategies by evaluation, interviews and documentation are the methodology used in this analysisIdentification of informants using purposeful sampling in this report. In this research, the data analysis technique is an interactive model analysis technique (interactive analysis model) with data analysis procedures covering three steps, namely: reducing data, presentation of data and description of conclusions. It can be inferred from the results of the analysis that the school ability complies with the new student admission implementation guidelines set out by the Banyuasin District Education Office. The model of measurement describes the relationship between the variables and their measures, and the relationship between variables is clarified by the structural model. With the 9 metrics studied, it is concluded that new student admission Online State Senor High School 1 Banyuasin II could be said to have performed well in general. From the 9 indicators evaluated, it can be seen that there are 4 indicators that have not been maximized, including selection execution indicators, registration criteria, selection time and selection performance, which also need to be improved.
\end{abstract}

Keywords: Management, Administration of Admissions, New Students, Online

\section{INTRODUCTION}

The government has declared that the admission of new students must be transparent and accountable. So that information can be accessed directly by the community, especially parents of students who will send their children to school. Admission of students to primary or secondary education units must be objective, open, accountable and non-objective discriminatory [1].

It is important to study and test it through this research activity to find out whether the current student admission system with PPDB in high school has met these requirements. A relatively young government high school, State Senior High School I Banyuasin II. Since this State Senior High School was established only in 2010. State Senior High School I, though not a superior school, has performed well in non-academic fields in terms of its independence.

"To carry out the program of introducing new student admissions through online and counseling for students who still have trouble interpreting the information provided, this data and information is required. Lack of community socialization, particularly for student parents, regarding information on new student admissions through online student admissions (PPDB). For the success of this operation at Banyuasin
Public High School Regency In terms of inadequate school oversight in many schools, there are still barriers to the regular incidence of delays in providing information on the collection of new student admissions (PPDB) online. The lack of good preparation in some schools is another issue, such that the timetable for the introduction of the New Student Admissions Online does not comply with the target activity plan.

\section{THEORY ANALYSIS}

\subsection{The Management Description}

There are experts who claim that Latin comes from the word management, which comes from the word "mantis" meaning hand and "agere" meaning to do. The two words are fused into the "manager" verb, which means to treat. In the form of the verb "Managere" with the noun "to manage" and "management" for people who conduct management tasks, "manage" is translated into English. [2]

\subsection{The Management Meaning}

Management comes from the word management in Peter Salim and Yenny Salim's Major Contemporary Indonesian which means leading, guiding, coordinating, and seeking to be stronger, more advanced, and partially responsible for some workers [3]. Management is a mechanism that helps to formulate strategies and 
priorities, to supervise all problems involved in the execution and accomplishment of objectives [5]

\subsection{Objectives for Management}

The aim of management is to transfer all existing resources in an organisation, such as human resources, equipment or facilities, in such a way as to avoid spending all time, energy and material to achieve the desired objectives. In all organisations, management is needed, since all efforts will be lost without leadership or management and it will be more difficult to accomplish goals. Here are some management goals: To achieve organizational goals based on the vision and purpose of the organization [6].

a. To maintain a balance between objectives that clash. In order to maintain a balance between the priorities, goals and actions of the opposing parties in an organization, management is required.

b. To attain effectiveness and performance. The function of an organization can be calculated in several distinct ways. Performance and effectiveness are one of the common routes.

\subsection{Role for Management}

Managerial functions are one field which continues to receive the attention of scientists and practitioners. This area gets serious attention because the managerial performance of an individual is essentially expressed and calculated by his ability to execute all of these functions. classified 5 aspects of managerial functions, namely planning, coordination, movement, monitoring and evaluation. Time and it is not possible to differentiate. $\mathrm{He}$ is accountable to supervisors, colleagues, directors or similar groups, and subordinates.

\section{Good leadership includes:}

a. Preparation is the choice of facts and an attempt to connect facts to each other, then to make predictions and projections of situations and, if necessary, to devise possible measures to achieve the desired results.

b. Organization is characterized as the implementation of all activities to be carried out between working groups and the determination of certain authorities and responsibilities so that business unity is maintained in order to achieve the specified objectives.

c. In order to accomplish a goal set in accordance with the planning and organizational trends, activation (Actuating) puts all members of the community to work consciously.

d. Controlling is characterized as the process of deciding what is being done, the measurement and correction of the implementation activities and, where appropriate, the corrective action taken on the implementation activities can be carried out according to the plan [7].
2.5. Online New Student Admission Based on the Minister of Education and Culture Regulation Number 44 of 2019

New pathway method for student enrollment is by online methode. Its under The Legislation of the Minister of Education and Culture on the Admission of New Students to Kindergarten, Primary, Middle School, High School and Vocational Schools governs the new student admission itself [8]. The online new students admission seeks to ensure that the admission of new students is carried out in an objective, open, accountable, non-discriminatory and equitable manner, in order to facilitate improved access to education services. Furthermore, new students admission is also a government initiative to equalize education, so again there is no, some schools are really involved in registrants, Some other schools are less involved, however.

\section{a. Road of Achievement}

The Achievement Path is a path for prospective students who have accomplishments and are outside of the zoning of the school as long as they meet the requirements. As a selection determination, national examination or school examination scores and achievement from the competition can be used. According to the requirements of each zone, the quota for achievement paths can be flexibly tailored to the quotas for other routes.

\section{b. Transfer Path for Parents}

The path of moving parents is a route that can be aimed at children of teachers as well as prospective applicants from outside the region concerned because their parents have moved home because of assignments, as evidenced by the existence of an assignment letter. The maximum quota of students received is $5 \%$ (five\%) of the total capacity of the school.

\section{c. Path of Affirmation}

The affirmation channel is intended for applicants who come from underprivileged economies, as demonstrated by involvement from the central government and local governments in the initiative to deal with poor families. This route can also be used both from inside and from outside the zoning area for underprivileged participants. At least 15 percent of the quota on this affirmation line is (fifteen percent).

\section{d. Path Zoning}

The zoning route is a route intended for students residing in local government-established zoning areas. The address on family cards or other official documents must be based on the venue. This path also accommodates disabled students. The number of students admitted is at least 50 percent of the ability of the school (ninety percent). 


\section{METHODS}

The key study objectives are to evaluate the management of new student admission management online at Banyuasin II, Banyuasin Regency, State Senior High School I. A qualitative research process, the technique of collecting through observation, interviews and recording, is the technique used in this study. Identification of informants using purposeful sampling in this report. In this research, the data analysis technique is an interactive model analysis technique (interactive analysis model) with data analysis procedures covering three stages, namely: data reduction, presentation of data and drawing of conclusions.

\section{RESULTS AND DISCUSSION}

Based on the results of the study in the table above, it can be shown that the variables calculated using 5 (Five) Dimensions of the Principal of Madrasahs Strategy to Prepare to Improve the Quality of Education According to [9] with 16 indicators studied concluded in general by the Madrasas Head Strategy to improve the quality of education a

\section{CONCLUSION}

It can be inferred from the results of the analysis that the ability of the school is in line with the guidelines for the implementation of the PPDB laid down by the Banyuasin Regency Education Office. The model of measurement describes the relationship between variables and their measures, and the relationship between variables is clarified by the structural model [10]. It is commonly assumed, with the 9 metrics tested, that PPDB Online State Senior High School 1 Banyuasin II can be said to have been well implemented. From the 9 indicators assessed, it can be seen that there are 4 indicators that have not been maximized, including the implementation of the selection indicators, Requirements for registration, selection period and outcomes of selection which also need to be improved.

In order to enhance the standard of current education, the school committee should be more involved in providing feedback to schools and tracking the new student admission online program. Schools should organize and establish harmonious cooperation with the community and approved officials more closely with other schools The Implementing Committee should pay more attention to how to decide the time to choose the most optimal and efficient online implementation of the PPDB by making careful planning according to field conditions and constraints.

\section{REFERENCES}

[1] Regulation No 13 of 2007 of the Minister of National Education on the expectations of principals of schools and principal duties of principals of schools
[2] Aaron-Aaron. (2010). Techniques for Sampling and Scale Collection. Bandung: University of Padjadjaran. "

[3] National Education Ministry Language Center, 2002. Major Indonesian Dictionary, Written I, Jakarta: "Balai Pustaka."

[4] Arafat, Y. Puspita, Y. Puspita, Y. (2020). Principal Leadership Management in Promoting Discipline for Teachers 1 SD Negeri 12 Betung, Universitas PGRI Palembang Journal of Teaching and Educational Media Innovation Vol. 1, No.1, Page: 10-17, September 2020. (downloaded, September 12, 2020)

[5] Salim, P., \& Salim, Y. (2012). Indonesian Dictionary Contemporary.

[6] With Safruddin A. J. (2014). Assessment of training services. Jakarta: Planet Alphabetisation. Jakarta: Cipta Rineka. "

[7] Terry, G. (2010). Dasar-Dasar Manajemen. Cetakan kesebelas. Jakarta: PT Bumi Aksara.

[8] Minister of Education and Culture Regulation (Permendikbud) Number 44 of 2019 on the admission of new students to kindergarten, primary, middle, high school and vocational schools.

[9] Ardhi, P. (2015). Student Admissions Management Assessment New Yogyakarta City Education Office Real Time Online System. Journal of Educational Science. Page 80-94, 8(1).

[10] PPDB Online Portal and Sumsel Prov Final Result Disclosure https://sumsel.siap-ppdb.com, PPDB Online Registration Guide 20192020 2021 SMA Province of South Sumatra State Vocational High School. 